\title{
RESISTING MARKET DISORDER AND ENSURING PUBLIC TRUST: REIMAGINING NATIONAL REGISTERS FOR LEGAL INTERPRETERS IN THE UNITED STATES AND THE EUROPEAN UNION
}

\author{
Melissa Wallace \\ melissa.wallace@utsa.edu \\ University of Texas at San Antonio
}

\begin{abstract}
This article aims to describe the current state of affairs as regards national registers of legal interpreters and translators (LITs) in the United States and the European Union. After a brief overview of what translation and interpreting studies researchers and EU project participants recommend about their construction and utilization, a case will be made for the use of national registers as essential tools in two important struggles: professionalizing legal translation and interpreting and building public trust. Based on current models and recommendations by researchers, a proposal will be put forth for minimum characteristics of a national register of LITs. Rather than an afterthought, the interpreter register merits scrutiny and careful elaboration precisely because of an ever more ubiquitous need for states and countries to implement measures which are fair, transparent, cost-effective, which guarantee due process, and which provide users with ways to make an objective value judgment regarding the competence of the interpreters they commission.
\end{abstract}

\section{Resumen}

El presente artículo pretende describir el estado de la cuestión de los registros nacionales de intérpretes y traductores judiciales en los Estados Unidos y en la Unión Europea. Después de examinar brevemente las recomendaciones de investigadores y participantes en proyectos especializados a nivel europeo, se defenderá la importancia de utilizar los registros nacionales para dos fines importantes: profesionalizar la traducción y la interpretación judicial, así como fomentar la confianza pública. A continuación se planteará una propuesta, basada en modelos actuales y recomendaciones 
de investigadores que contempla las características mínimas de un registro nacional. Debido a la necesidad cada vez más presente de implementar medidas que sean justas, transparentes, sostenibles y que protejan los derechos procesales de los ciudadanos, el registro debe ser elaborado cuidadosamente y con el esmero apropiado. Así también se puede garantizar que los usuarios de dichos registros dispongan de información objetiva sobre la competencia de los intérpretes a quienes contratan.

Keywords: Legal interpreting. European Directive. Professionalization. National register. Regulation.

Palabras clave: Interpretación judicial. Directiva Europea. Profesionalización. Registro nacional. Regulación.

Manuscript received on July 15, 2014

and accepted for publication on September 30, 2014. 


\section{Introduction: National Registers at a Turning Point}

Recent and vital work to guarantee language rights in criminal and civil proceedings is currently being carried out both in Europe and the United States. In the European context, Member States are in the process of implementing Directive 2010/64/EU, a measure which aims to guarantee adequate ${ }^{1}$ translation and interpreting in criminal proceedings. Similarly, in the United States efforts are being undertaken by the newly configured Council of Language Access Coordinators (CLAC) $)^{2}$ as it becomes more and more apparent that, in spite of enjoying robust legislative support, language access continues to be an uphill battle in many US courts. In a forcefully-worded guidance letter issued by the Civil Rights Division of the US Department of Justice on August 16th, 2010, Assistant Attorney General Thomas E. Perez addressed all chief justices and state court administrators. The letter acknowledged that "despite efforts to bring courts into compliance, some state court system policies and practices significantly and unreasonably impede, hinder, or restrict participation in court proceedings and access to court operations based upon a person's English language ability" (Perez 2010: 2).

Both Europe and the United States face challenges in guaranteeing due process rights while endeavoring to comply with legislation in the face of

1. Article 2, paragraph 8 of the Directive states that "Interpretation provided under this Article shall be of a quality sufficient to safeguard the fairness of the proceedings, in particular by ensuring that suspected or accused persons have knowledge of the case against them and are able to exercise their right of defence" (Directive 2010: 5).

2. Presumably in response to Department of Justice insistence on greater oversight in matters concerning language access, in the spring or summer of 2012 the Council of Language Access Coordinators (shortened to CLAC, like the Consortium for Language Access in the Courts before it) was chartered. The Council of Language Access Coordinators differs markedly from its predecessor in that it "consist(s) of individuals designated by the COSCA (Conference of State Court Administrators) member in each state who are interested in or associated with the provision of language access services to the courts, such as language access program coordinators" (COSCA n.d.: 1). A representative of every US state and territory (the Language Access Coordinator) has now been designated to be the point person for the provision of language access services to the courts. 
budgetary constraints, anti-immigrant sentiment, and limited access to qualified interpreters. Members of law enforcement and officers of the court often do not know how to locate interpreters who work in languages of limited diffusion (LLDs) and, even when they can, they often have virtually no way of knowing objectively how skilled the person may actually be as an interpreter. As vast territories which are ethnically and linguistically diverse, the European Union and the United States share similar challenges and are being asked to formalize mechanisms by which all court participants are guaranteed equal footing in the courts through the use of qualified interpreters (Blasco Mayor, Del Pozo Triviño, Giambruno, Martin, Ortega Arjonilla, Rodríguez Ortega \& Valero Garcés 2013; COSCA n.d.; Corsellis 2011; Directive 2010; Morgan 2011; Ortega Herráez, Giambruno \& Hertog 2013; Pérez 2010). This article posits the use of a national register, often referred to as a registry or a roster in the United States, as a tool that can give administrators the information they need about an interpreter's skills while at the same time offering legal interpreters and translators (LITs) a multi-faceted tool in the struggle towards professionalization.

While there is no official nationwide or state-level mandate to create a national register of qualified interpreters in the United States, the European Union does, in fact, have such a mandate. As a requirement for admission, all EU Member States are signatories to the European Court of Human Rights (ECHR). Article 6 of the ECHR provides that anyone facing a criminal charge should be provided with the services of an interpreter, free of charge, if $s /$ he does not understand the language of the proceedings (Morgan 2011: 5-6). The European Commission found, however, that cost was often an impediment to Member States in fulfilling their ECHR obligations; that interpreters and translators often worked under poor conditions; and that Member States had difficulty recruiting sufficient LITs given that "the profession suffers from a lack of status, with translators and interpreters sometimes being poorly paid, not having social benefits (such as paid sick leave and pension rights) and complaining that they are not consulted enough by their counterparts in the legal profession" (Morgan 2011: 6-7). Much like in the United States, it became clear that longstanding non-compliance with existing laws was pervasive, similar to the way that many US states continue to act in direct violation of Title VI of the Civil Rights Act (Ortega Herráez, Giambruno \& Hertog 2013; Wallace forthcoming). One powerful remedy has been the aforementioned EU Directive, which has been the driving force behind the establishment of minimum education requirements, systems of accreditation, continuing education requirements, and the elaboration of codes of ethics and standards of 
practice. Directive 2010/64/EU states that "The implementation of the principle of mutual recognition of decisions in criminal matters presupposes that Member States have trust in each other's criminal justice systems" (Directive 2010: 1), and finds that one of the key initiatives to aid in this endeavor is the building and sharing of information based on harmonized, reciprocal standards. Specifically, Member States are directed to facilitate access to national databases of legal translators and interpreters where such databases exist (Directive 2010: 4). Furthermore, article 5, paragraph 2 states that

In order to promote the adequacy of interpretation and translation and efficient access thereto, Member States shall endeavor to establish a register or registers of independent translators and interpreters who are appropriately qualified. Once established, such register or registers shall, where appropriate, be made available to legal counsel and relevant authorities (Directive 2010: 6).

Multiple efforts have been made at the level of European Commission-funded work groups and projects to tackle a variety of aspects of training and credentialing court and legal interpreters. In a Europe that invests heavily in the model of a multicultural and multilingual society and which boasts a historically well-established history of translator and interpreter training (Pym 2014: 186), the construction of national registers promises to build in all of the elements with which status within a profession is signaled, including aspects such as credentialing, oversight, and professionalism. To that end, this article aims to describe the current state of affairs as regards national registers of legal interpreters and translators in the United States and the European Union. While generalizations about the EU or the US (along with any attempt to impose common solutions across the board) may at the surface appear to ignore the individualities and complexities of each set of systems, their commonalities are striking. Both bodies consist of linguistically and culturally diverse states with varying histories of credentialing, testing and training. Most, if not all, are faced with identifying qualified interpreters in languages of lesser diffusion. The mere fact that the parts of the whole work independently and sometimes at odds with each other creates the opportunity to explore the benefits of consistency and harmonization.

Accordingly, after a brief overview of what translation and interpreting (TI) studies researchers and EU work group participants recommend about their construction and utilization, a case shall then be made for the use of national registers as essential tools in two important struggles: professionalizing legal translation and interpreting, and building public trust. Although the creation of national registers has already occurred in a handful of European 
nations, many still do not comply with this feature of the Directive. In the United States, initiatives are in their infancy. Furthermore, this article aims to go beyond the vision of the register as a mere list of practicing professionals, contemplating registers as a tool for professionalization, an aspect which remains under-examined in current scholarship.

Based on current models and recommendations by researchers, a proposal will be put forth which posits minimum characteristics of a national register of LITs. Rather than an afterthought, the concept of the interpreter register merits scrutiny and careful elaboration precisely because of an ever-more ubiquitous need for states and countries to implement measures which are fair, transparent, cost-effective, which guarantee due process, and which provide users way to make a value judgment regarding the competence of the interpreters they commission. By making interpreters' qualifications transparent, registers can contribute directly to the public trust. In turn, low morale and market disorder can be mitigated by approaching the register as a vehicle for interpreter professionalization.

\section{The Current State of Affairs in the EU and the US: National Registers in Theory and in Practice}

Among the flurry of initiatives, studies, policy analyses and work group final reports which have been generated by various European Commission projects in anticipation of the transposition of Directive 2010/64/EU, interpreter registers are often mentioned, seldom described, and almost never critically examined. The need for searchable databases seems to be taken for granted, but current research reflects few efforts to carefully analyze their utilization and composition. There are notable exceptions, nonetheless. The following section reviews the state of the art of the interpreter register, in practice and as described by scholars and policy work groups. Subsequently, the extent to which such registers exist currently in the European Union and the United States is deliberated.

\subsection{Recent Scholarly Explorations of National Registers}

Beyond the confines of European Union work groups, scholarly treatments of the topic of national registers of interpreters are scarce. The most comprehensive discussion on the subject of national interpreter registers comes from a team of authors headed by Ann Corsellis, Vice President of the Chartered Institute of Linguists of the United Kingdom. Corsellis and her colleagues maintain that "A national register has obvious advantages for setting professional 
standards, making accredited PSI (public service interpreter) skills more easily accessible and making available the widest possible range of language combinations countrywide" (Corsellis, Cambridge, Glegg \& Robson 2007: 139) and, indeed that is exactly what the UK's National Register for Public Service Interpreters (NRPSI) provides. As a well-constructed, monitored and comprehensive model to emulate, the NRPSI was established in 1994. Having separated from the Chartered Institute of Linguists in April of 2011, the NRPSI today serves as an independent voluntary regulator, prescribing qualifications, ensuring that standards for conduct are met, and investigating complaints ${ }^{3}$. It boasts an office team of five full-time and two part-time employees and is financed mainly through a combination of fees from interpreters and subscriptions from the public services (Corsellis, Cambridge, Glegg \& Robson 2007: 142). The UK's National Register has long recognized that a profession arises where trust has to be engendered, and there is inherent value in having access to interpreters who have had a prior objective assessment of their language and professional skills and who are required to observe a code of conduct. The NRPSI is free, accessible to the public, and fully searchable online.

On a more regional level in Italy, Mette Rudvin describes two strands of the LEGAII (Legal interpreting in Italy: Training, Accreditation and the Implementation of a National Register) project at the University of Bologna. With the overarching goal of creating constructive, collaborative relationships between the university and local Bologna institutions, Rudvin suggests that the creation of a national register is crucial to the project's success. Since in Italy there is currently no system of certification or accreditation for court interpreters, the LEGAII project is tasked with setting up a register, at least at the regional level, that is in accordance with the EULITA project that is currently underway to create standards across the EU for an interpreter database (Rudvin 2014: 78). While LIT stakeholders from the United States may not be familiar with EULITA (the European Legal Interpreters and Translators Association) ${ }^{4}$ nor

3. http://www.nrpsi.org.uk/.

4. The TRAFUT (Training for the Future) final report describes the role of EULITA and the national associations it represents in its memberships as "crucial in assisting Member States during the implementation process (of Directive 2010/64/EU). The steps that have been taken towards the provision of quality legal interpreting and translation in the EU, an EU code of conduct guaranteeing cross-border integrity, best practice working arrangements with other legal professionals in multilingual criminal proceedings, the setting up of national registers, etc., will affect not only the system operation of all Member States in this area but even more importantly, trickle down to all EU citizens who find themselves involved, be it as a witness, victim or defendant, in a criminal proceeding across languages" (n.d.: 10). 
with the various projects that the organization sponsors and reports on, it is within these project work groups that nearly all systematic studies regarding national registers are to be found. There appear to be no formal examinations of the creation or administration of national registers within US scholarship nor in other areas of the world beyond Europe. For this reason, an examination of the current state of affairs of national registers would be incomplete without an overview of the EU projects which have acknowledged the role of the register or proposed active solutions in preparation for the transposition of Directive 2010/64/EU.

\subsection{EU Projects and National Registers}

On February 19th, 2003, the European Commission presented a Green Paper on Procedural Rights in Criminal Proceedings for Suspects throughout the EU. The Green Paper maintains that Member States must:

... have a system for training specialised interpreters and translators ending with a recognised certificate; have a system for accreditation of such translators and interpreters; introduce regulations for registration which must not be unlimited so as to encourage the persons involved to keep up their knowledge of the language and of legal procedure, if and when they wish to renew their registration; set up a system of continuous professional development so that legal interpreters and translators will be able to maintain their skills at a proper level; draw up a code of conduct and guidelines for proper working standards which must be equivalent throughout the EU or correspond as far as possible; and provide training for judges, public prosecutors and lawyers so that they will have a better insight into the role of the translator and the interpreter, resulting in a more efficient mutual collaboration (Hertog \& Van Gucht 2008:15-16).

The resulting Status Quaestionis Questionnaire on the Provision of Legal Interpreting and Translation in the EU published in 2006 was a follow-up to previous projects, and its primary objective was to examine "the state of affairs concerning one fundamental procedural right, i.e. the right to access to justice across languages and culture or in other words, the right to a free interpreter and the translation of all relevant documents in criminal proceedings" (Hertog \& Van Gucht 2008: v). The EU-wide questionnaire compiled composite country profiles of each Member State and weighed and ranked countries on a number of essential performance indicators, the most relevant to this article being those related to regulation of the profession. The report's authors argue that "National registers of equivalent standard and common codes of conduct could allow mutual access, provided there were also equivalent similar professional frameworks for employment and good practice" 
(Hertog \& Van Gucht 2008: 196). Foundational efforts such as the information-gathering Status Quaestionis and the Green Paper on Procedural Rights were supported and disseminated by the aforementioned EULITA. Although there are several European Commission-funded projects which focus on various ways to facilitate the successful transposition of Directive 2010/64/EU those which have contributed most to an international dialog on national registers are, indubitably, Aequitas and TRAFUT (Training for the Future).

The Aequitas (Access to Justice across Language and Culture in the EU) study makes specific recommendations about the registration of LITs, citing the National Register of Public Service Interpreters in the UK as an example. The authors recommend making registration obligatory, "which means that interpreters and translators who are not registered in the National Register cannot work for the police and the legal services, and that the police and the legal services are obliged to use only registered interpreters and translators" (Grollmann, Martinsen, \& Rasmussen 2001). Furthermore, the authors recommend utilizing national registers to cover several services at the same time including hospitals, schools, and social welfare organizations, effectively creating an all-encompassing public service interpreter register similar to the UK model. Authors Grollmann, Martinsen and Rasmussen also posit recommendations about what the register should contain, including areas of specialization and interpreter availability, and recommend differentiation, meaning that interpreters at different stages of professional development would appear on the register at different tiers or levels.

The TRAFUT (Training for the Future) project team was formed and funded in order to "assist all relevant stakeholders such as ministry officials, the various legal professions involved (judges/magistrates, prosecutors, lawyers and the police), as well as the associations and training institutes of legal interpreters and translators during the process of implementation [...] of this Directive (2010/64/EU)" (TRAFUT n.d.: 4). The project leaders held four workshops throughout the EU during 2011 and 2012 in Ljubljana, Slovenia;

5. More information about the QUALITAS (Assessing Legal Interpreting Quality through Testing and Certification) project can be found at http://www.qualitas-project.eu/custom-user/112 and QUALETRA (Quality in Legal Translation) at http://www.eulita. eu/qualetra-0. The AVIDICUS 3 project (http://www.videoconference-interpreting. net/?page_id=154) focuses on the use of videoconferencing in bilingual legal proceedings that involve an interpreter. The ImPLI project (Improving Police and Legal Interpreting) at http://www.eulita.eu/impli-improving-police-and-legal-interpreting) positively acknowledges the Directive's inclusion of a need for registers and discusses them briefly in terms of usefulness for recruitment purposes. 
Madrid, Spain; Helsinki, Finland; and Antwerp, Belgium ${ }^{6}$. The meetings featured experts from the EU Commission, the Directorate-General for Justice, the Secretariat of the EU Council, the European Court of Justice, the European Court of Human Rights, the European Criminal Bar Association, the Council of Bars and Law Societies in Europe, and the European Forum of Sign Language Interpreters, in addition to judges, prosecutors, lawyers, police officers, representatives of ministries of justice and of national professional associations of legal interpreters and translators, academics and trainers. Among other final recommendations, TRAFUT's final report proposed a basic outline of a national register of legal interpreters and translators based on presentations which touched on the use, administration, development and implementation of national registers (TRAFUT n.d.: 13-16). Indeed, these EU contributions to the international dialog on the import of national LIT registers stand alone, serving as potential models for initiatives in the United States and other parts of the world.

\subsection{The Current Reality of National Registers in Europe and the United States}

At present there is no nationwide, spoken-language roster of court and legal interpreters in the United States. As a rather fractured set of systems, each state has the authority to train, accredit and hire LITs based on whatever criteria they establish. An exploration of the court interpreting / language access web site portal for each US state and territory reveals that out of 50 states and the five territories of American Samoa, Guam, the US Virgin Islands, Puerto Rico, and Washington DC, 28 states or territories (50.9\%) have no publicly searchable lists or databases of court interpreters. Of those that do, 11 have electronic searchable databases and 16 have lists in the form of pdf files. The databases and lists contain a combination of domains such as name, language, location, level of qualification, and availability (distance willing to travel, willingness to work nights and weekends, etc.). All interpreter rosters differentiate levels of competence in some way, usually from two to four levels, although the array of qualifying adjectives describing the various tiers is dizzying. There is no comprehensive database which marries the information available on individual state courts' web sites.

6. Links to the agenda of the four TRAFUT workshops and selected presentations can be accessed at http://www.eulita.eu/training-future.

7. Interpreters are designated as certified, master, registered, and qualified, among many other options. 
There is one initiative taking place at the national level in the United States which is geared towards the construction of a national register of interpreters who can provide services remotely. The work group members consist of Language Access Advisory Committee (LAAC) members as well as state court interpreter program managers who were selected for having robust remote interpreting projects already existing in their states, or who had some other related special interest or area of expertise. The group's overarching objectives are to improve access to more qualified interpreters and to explore and develop the use of technology which will, theoretically, be more cost efficient in the long run. The template for the register was built from scratch by the National Center for State Courts, but the work group's intention is to populate the national register with information from all states whose interpreters wish to be listed on it and who fit the criteria for inclusion (C. Capati, personal communication, June 24, 2014). The register will be searchable by language and will be differentiated by tiers based upon various existing levels within state programs ${ }^{8}$. At this time the domains contemplated for the national register will be basic, and will include each interpreter's name, state, city of residence, language, tier (level of certification), phone number, email, and availability for in-person, audio or video sessions. The registry will be available to the managers of each state's court interpreting program and possibly later on to vendors, although it is still not clear when the register will go live, what systems will be in place to manage and update it, how many staff members it will require, and whether or not the register will generate any revenue. The National Center for State Courts will maintain the registry.

Furthermore, the issue of requiring interpreters to abide by a code of ethics and potentially sanctioning them is an issue that is being worked on as the team develops protocols for inclusion on the registry. Since there is currently no national code of ethics (states have individual codes), the question of discipline is unclear and the issue of jurisdiction needs to be discussed further. Similarly, if an interpreter does not comply with continuing education requirements in states that require them, it is unclear what the consequences

8. Tier differentiation proved to be somewhat controversial, according to Capati (2014). A few of the "sticky issues" identified include the fact that some states will not recognize an interpreter's test scores from another state if that person passed the test using a partial pass system. Some states also use a "master" level which includes those who passed the FCICE (Federal Court Interpreter Certification Examination) or those who passed the CLAC (state-level) oral test at $80 \%$ or higher on all sections. In some states, each individual sight translation section must be passed at $70 \%$ while in others a minimum of $65 \%$ is acceptable as long as the composite sight translation score is at least $70 \%$ (C. Capati, personal communication, June 24, 2014). 
will be or how compliance will be monitored. As regards enforced usage of interpreter selection based on highest level of accreditation, the work group hopes that each state will start with the most qualified interpreter and work their way down the roster based on availability, but a selection procedure is not to be mandated at this time (C. Capati, personal communication, June 24, 2014).

The overall panorama of national registers is quite similar in the Member States of the European Union, where there are currently national registers in only a handful of countries including Slovenia, the Czech Republic, Finland, Ireland, Luxemburg, Malta, Holland, Slovakia, Sweden, Spain, and the United Kingdom (Blasco Mayor, Del Pozo Triviño, Giambruno, Martin, Ortega Arjonilla, Rodríguez Ortega \& Valero Garcés 2013). It is notable that of the six countries represented on the ImPLI work group (which focused more on police interpreting and included Belgium/Flanders, the Czech Republic, France, Germany, Italy, and Scotland/UK), three countries had national registers and three did not. Some did have local and /or regional registers, however (ImPLI n.d.: 59-71).

The two European countries in which ample reflections upon national registers and the state of LIT professionalization have been published are certainly the United Kingdom and Spain; the former, perhaps for having the most elaborate, independent and longstanding national register, and the latter for having such a robust tradition of training and research that few questions related to the field go unexamined ${ }^{9}$. As an established tool which fulfills a vital social and public function, Corsellis (2000) discusses how the NRPSI has a role in enabling the public services to fulfil their responsibilities. The UK Register goes beyond providing suitably qualified LITs to creating management structures which support access to services. In Spain, in contrast, "the 'register' itself is a pdf document on a webpage, not a database, and there is no management whatsoever" (Blasco Mayor 2013: 170). Furthermore, in addition to being so out of date that cases of deceased translators and interpreters still being listed have been reported (2013: 188), Blasco Mayor identifies the current national Spanish register as being utterly ineffectual. Not only does it not list interpreters in some of the languages most needed in court and police settings as there are no LITs registered for those languages, but additionally, the lack of regulation of the profession directly impacts the

9. Spain is the only European country boasting 22 universities that offer translation and interpreting degrees (Blasco Mayor 2013: 166), and currently there are 19 active translation studies journals published there (Franco Aixelá 2012: 340). 
register's engendering of public trust. Quality is simply unaccounted for. In sum, "the Ministry cannot guarantee that services provided by the translators it certifies are quality translations or interpreting since it performs no quality control over their work nor has any control over the number and type of assignments they accept" (Blasco Mayor 2013: 170). Things are bound to look up, however. One of the latest EU projects, LIT Search ${ }^{10}$, is a pilot project aimed at exploring the modalities and practical features of national databases which will eventually be linked. The project, coordinated at KU Leuven, will include sign language interpreters and will eventually be housed on the e-justice portal, a site that is envisioned to function as a sort of one-stop shopping place for all justice-related matters.

\section{Raising Expectations: What can a National Register do for the Profession?}

Legal and court interpreting is still very much an emerging profession. Scholars who subscribe to Trait Theory place both signed and spoken language interpreting in a state of market disorder (Tseng 1992; Mikkelson 2013; Hessmann, Salmi, Turner \& Wurm 2011), described as "the current state of the interpreting market that reflects significant instability related to minimum standards for entry into the field and a lack of consistent and reliable professional control over the variables impacting the effective delivery of interpreting services" (Mikkelson 2013: 71). The focus of this study is to examine those aspects of market disorder which can be mitigated and contravened through the development of differentiated interpreter registers, advocating for their construction and enforced utilization. In addition to aiding in the evolution of interpreting as a profession, national registers can also contribute to transparency and public trust.

\subsection{Registers to Combat Market Disorder}

The current state of public service and legal interpreting as a profession has been explored by researchers analyzing the sociology of professionalization through lenses such as Bourdieu's concept of distinction (Monzó 2009). Others postulate the training of public service providers as part of the march towards professionalization (Corsellis 2000; Salaets 2012). Two other major theories discussed in articles about the professionalization of both spoken

10. See http://www.eulita.eu/lit-search-\%E2\%80\%93-pilot-project-eu-database-legal-interpreters-and-translators. 
language and signed language interpreting include Trait Theory and Control Theory, both of which place interpreting into the category of a professionalizing occupation (Tseng 1992; Witter-Merithew \& Johnson 2004; Monzó 2005; Pym, Grin, Sfeddo \& Chan 2012; Mikkelson 2013).

Not to be confused with the psychological theory related to the human personality which bears the same name, Trait Theory takes the view that a profession is an occupation with certain characteristics (Winter 1988: 21) and, depending on the nature of said characteristics, an occupation is said to be further along (or not) in the professionalization process. Control Theory examines professional power, such as the extent to which an occupation exercises control over the determination of the substance of its work while also taking into account the extent to which specific occupations have progressed in their struggles for professional status (Tseng 1992: 19-20). Trait Theory overlaps with Control Theory in the insistence that a consolidated profession defines expertise on its own, without having content of knowledge imposed upon it by other professions. Scholars such as those previously mentioned tend to find common ground when identifying the "traits" or "signals" that a bona fide profession encapsulates. These include characteristics such as specialized knowledge, fraternity, self-regulation (Monzó 2005), formal study, a recognized degree of expertise, and licensure or accreditation. Others include elements such as initial and in-service training, recognized assessment at all levels, guidelines to good practice, and disciplinary procedures (Corsellis 2011).

Unfortunately, court and legal interpreting continues to be largely unregulated both in Europe and in the United States. Interpreters as well as litigants are unprotected, and in discussions surrounding professionalization, there is no small amount of anecdotal and scholarly discussion of the problems that continue to beset public service interpreting. Such deficiencies include low wages ${ }^{11}$, low social prestige, misunderstanding by society, and very limited authority or power over the working conditions and standards that are established, severely limiting the collective authority of the field (see Bell 2000; Helmerichs 2004; Witter-Merithew \& Johnson 2004; Monzó 2005 \& 2009; Hessmann, Salmi, Turner \& Wurm 2011; Blasco Mayor 2013; Rudvin 2014).

11. The ImPLI final report finds that "... there is a notorious lack of funds (for police interpreting), which means that in most cases the only selection criterion is price. As a result, poor remuneration often means poor quality since qualified interpreters do not accept police interpreting assignments under such conditions. Poor quality of unqualified interpreters is also one of the reasons for the mistrust among the police as far as working with interpreters is concerned" (n.d.: 17). 
When credential requirements for employment vary, when there exists a lack of consensus between the profession and the market place as to the common attributes of an entry-level practitioner, or when there is insufficient consumer and public appreciation assigned to the complex work of interpreting, market disorder ensues, both for signed language and spoken language interpreting (Witter-Merithew \& Johnson 2004; Mikkelson 2013).

Market disorder, also referred to as market disorientation, is described by Joseph Tseng as follows:

Practitioners in the market cannot keep outsiders from entering practice. They themselves may have started practice as outsiders or quacks. Recipients of the service either have very little understanding of what practitioners do or very little confidence in the services they receive. It is very likely that the public simply does not care about the quality of the services. Hence, distrust and misunderstanding permeate the market. What matters more to clients, in the absence of quality control, is usually price. Whoever demands the lowest fees gets the job. Therefore, advertising and price-cutting are commonplace in the market. The rights of the clients are normally not protected, and malpractice as a result frequently occurs. When the clients need services, they simply call upon anyone who is around and asking a reasonable fee. Clients who demand quality services are usually troubled by the fact that they do not know where to get qualified practitioners for services (Tseng 1992: 44-45).

As a response to market disorder, "employers tend to trust professional experience or their own recruitment tests rather than academic qualifications or membership of an association" (Pym, Grin, Sfeddo \& Chan 2012), and potential clients and users of interpreter services often mistrust practitioners in this phase of professionalization. A well-constructed and faithfully utilized register, however, can lend transparency to interpreters' skills, aid in the profession's resistance to outsourcing and abusive language service provider (LSP) practices, fight against interpreter invisibility, postulate a roadmap to career progression for interpreters, and provide indispensable access to LITs who work in languages of lesser diffusion. Through transparency and accountability, furthermore, the EU Directive's need to engender public trust is more likely to be satisfied.

\subsection{National Registers and Public Trust}

The concept of mutual trust in other Member States' criminal justice systems is one of the very foundations of EU Directive 2010/64/EU. Article 2 insists that the "Interpretation provided under this Article shall be of a quality sufficient to safeguard the fairness of the proceedings, in particular by ensuring that suspected or accused persons have knowledge of the case against them 
and are able to exercise their right of defence" (Directive 2010: 5). To have any hope of being able to expect a minimum standard of adequate performance, the profession requires mechanisms by which a client can judge for him/herself the degree of quality of the services rendered at the point of delivery. Without some kind of regulation, "[...] the public loses its undoubted right to be protected from charlatans and crooks, to be guaranteed a product which is not substandard and to have recourse to an authority which can provide compensation if it is" (Bell 2000: 148).

Rudvin (2014) identifies the lack of transparency in interpreters' skills and competences as one of the major flaws in the current interpreter recruitment system in Italy, an argument which speaks directly to issues of quality. The ImPLI final report on police and legal interpreting in the EU makes the case that the lack of centralized registers has a direct effect on the lack of quality control. As the report laments the lack of centralized registers and quality assessment bodies, it proclaims that "National quality control systems do not exist. Local initiatives do exist but are too fragmentary at the present time. There is no system in place to verify the accuracy of interpretation and translation. In some countries (for example France, Belgium), there are not centralised registers of legal interpreters from which criminal justice authorities can select interpreters" (ImPLI n.d.: 39).

Moreover, registers can reflect understanding of and adherence to codes of ethics and standards of practice. The regulation of practice provided through the codes of conduct allows for its members to commit to disciplinary procedures where breaches of the code are alleged and, when necessary, appropriate action can be taken (Corsellis 2004: 126). While the existence of a code of ethics does not oblige people to abide by it, interpreter breaches have repercussions on the profession as a whole, diminishing the public trust that is so crucial (Hale 2007: 105). In terms of public trust, a freely available national register characterized by transparency can be a powerful tool. In the absence of such transparency, "[un] registro de operadores que no garantice la calidad necesaria no contribuye a la confianza mutua ni a la seguridad jurídica deseadas" (Blasco Mayor, del Pozo Triviño, Giambruno, Martin, Ortega Arjonilla, Rodríguez Ortega \& Valero Garcés 2013: 4).

\subsection{Beyond Professionalization and Public Trust: Other Important Uses of the National Register}

This article has focused on national registers of LITs as a weapon against market disorder and as an aid to transparency and building the public trust. However, national registers have additional professionalizing capabilities. If 
their usage is enforced and relied on by users across court and criminal justice systems, national registers can aid in the resistance against outsourcing of interpreting work to agencies, as currently happens in several EU countries and several US states, putting LITs in harm's way of abusive practices at the hands of unethical language service providers.

Blasco Mayor (2013: 170) explains Spain's dubious honor of having been the first European country to outsource court interpreting services in 2003, a state of affairs which she believes has led to the current situation in which chaos and absence of professionalism reign. There is no quality control, no training or certification required, and fees paid by the service providers are akin to those of an unskilled worker ${ }^{12}$. Unfortunately, the United Kingdom followed Spain's controversial lead in early 2012 (Ortega Herráez, Giambruno $\&$ Hertog 2013), privatizing court interpreting services to disastrous effect as "Rates for interpreters were slashed to barely subsistence levels overnight, leading to the vast majority of interpreters choosing to boycott the new contract rather than accept ... pitiful pay and conditions ${ }^{13}$." Having recourse to a vendor-neutral recruitment source, especially for interpreters of LLDs, could provide a viable alternative to outsourcing, the effects of which were so devastating for LITs in the United Kingdom that the nation's contract with a private language services provider

...ha sido objeto de una investigación en el seno del Parlamento británico a cargo de la Comisión Parlamentaria de Justicia $[\ldots$ y...] a causa de este mal paso, el anterior Ministro de Justicia británico tuvo que dimitir, y la actual Ministra no tiene el apoyo ni siquiera de su propio grupo parlamentario con respecto al actual modelo de provisión de traductores e intérpretes judiciales en su país (Blasco Mayor, del Pozo Triviño, Giambruno, Martin, Ortega Arjonilla, Rodríguez Ortega \& Valero Garcés 2013: 5).

Conversely, national registers can act as a ladder of opportunity for career progression, setting out a roadmap of professional upward mobility for interpreters in terms of credentialing and training. What Corsellis, Cambridge, Glegg \& Robson (2007) describe as "levels of membership", and what is referred to often in the United States as differentiation or tiers, "...provides a professional

12. "In Spain the administration pays up to 60 EUR per interpreting hour to outsourced agencies, who in turn pay the interpreter between 8 and 12 EUR per hour. Pay is a major concern of the interpreters and low pay is a major disincentive" (Blasco Mayor 2013: 175). The Canary Islands Model discussed in the same article, however, shows a marked contrast with the rest of the country. With no agency to intervene, court interpreters were earning 44 euro per hour in 2008 (Blasco Mayor 2013: 172).

13. See http://www.opendemocracy.net/ourkingdom/joel-sharples/realities-of-outsourcingcourt-interpreters-mean-miscarriages-of-justice. 
structure through which linguists can develop their skills and earn professional status and recognition" (Corsellis, Cambridge, Glegg \& Robson 2007: 142). A publicly visible, oft-utilized and well-monitored path to higher status and recognition helps morale in addition to giving more objective information to the public, another way in which national registers can combat market disorder ${ }^{14} . "$

In a similar vein, then, it stands to reason that a national register functions also to undermine the traditional invisibility under which LITs have labored. At a time in which governments and society at large still cannot even tell the difference between a translator and an interpreter, even in a country such as Spain which boasts 22 universities that offer translation and interpreting degrees (Blasco Mayor 2013: 66), increased visibility contributes to the professionalization of LITs as well as functioning as a recruiting tool, especially for interpreters of languages of lesser diffusion.

\section{A Proposal: Rethinking National Registers}

Based on the models and findings discussed, a proposal can be made which pulls together the best attributes of a national register at the service of interpreter professionalization and public trust ${ }^{15}$. Active work groups exploring issues of the building of national registers would do well to consider the following positive attributes of a forward-looking register.

First and foremost, rosters should be differentiated, distinguishing between para-professional and professional practitioner competence. Not only should more advanced skills garner higher levels of compensation ${ }^{16}$, but "... the important thing is that the exact level of qualification and experience of each interpreter and translator appears clearly from the Register in order to ensure that the clients get the interpreter or translator who best matches their needs" (Grollmann, Martinsen, \& Rasmussen 2001). They should contain, at the very least, the criteria suggested by Corsellis (2004: 125): interpreter

14. As an example, the national register in Norway acknowledges that one of its functions is to "encourage interpreters to document and improve their skills and competencies." See http://www.eulita.eu/ljubljana-workshop.

15. The Comisión de la Conferencia de Centros y Departamentos Universitarios de Traducción e Interpretación (CCDUTI) makes explicit recommendations for an improved national register for Spain in Blasco Mayor et al. 2013.

16. While the decision to regulate minimum fees may be controversial or unwelcome in some countries, the TRAFUT final report recommends that countries enact legislation on LIT fees both for criminal and civil law proceedings (TRAFUT n.d.: 16). The CCDUTI group fully agrees (Blasco Mayor, del Pozo Triviño, Giambruno, Martin, Ortega Arjonilla, Rodríguez Ortega \& Valero Garcés 2013). 
qualifications, training undertaken leading to the examination, experience, security vetting, references as to character and suitability, and the practitioner's pledge to adhere to a code of conduct and to abide by disciplinary procedures in the case of a dispute. National registers should be fully searchable by any domain, and should include areas of expertise that may cross over into areas of other public services such as healthcare interpreting (and its related specialties), social services, and educational settings. At some point an online booking system might be considered.

Furthermore, in data collection as in data provision, consistency has its virtues and constitutes "one of the essential planks of good planning and organisation" (Corsellis 2004: 123). Harmonizing the domains across state and national lines in the interest of standards and consistency can only benefit the profession. The United States, especially, should seek to build a national register based on the "common platform" concept (Pym, Grin, Sfeddo \& Chan: 2012). Especially in the realm of interpreter credentialing/certification, harmonization acts as a guarantee of an interpreter's professional training and adhesion to a professional code of ethics. In an effort to learn from each state or country's best practices, creating equivalency could bring essential uniformity ${ }^{17}$. In other words, the practical benefits and judicial security inherent to reciprocity would equally benefit the United States as well as the Member States of the European Union.

The characteristic of national registers which would have the most profound effect on combatting market disorder and fomenting the public trust is the enforcement and requirement of its use: in other words, making the register a required first stop, with rules of law or statutes that require that the most qualified interpreter with the areas of expertise and the language combinations needed are contacted first. Even with good intentions and good will, non-compliance with state and federal laws requiring free language access in the courts still seems to be common fare in the United States (Schweda Nicholson 2004: 49). Until robust laws governing the use of national registers as tools to find the most appropriate and most highly skilled interpreter available are put into place, the use of uncertified and unqualified interpreters is likely to continue. In a similar vein, the TRAFUT final report, in its basic outline of a national register of LITs, recommends that countries enact legislation "in order to achieve uniform standards for the admission to registers and the

17. One caveat might be the irregularity in access to and quality of court interpreter training in the 50 US states. Nonetheless, it should be noted that there are currently no minimum training or educational requirements for attempting to earn certification as a court interpreter. 
administration of registers" (TRAFUT n.d.: 13). In more concrete terms, the report recommends that legislation be applied to specific aspects of a national register including admission to the register, contexts in which the interpreter can practice, and day-to-day management of the register (TRAFUT n.d.: 14). Aequitas authors Grollmann, Martinsen and Rasmussen argue that

[i]t should be made obligatory for the police and the other legal services to use only interpreters and translators from the Register, except in those circumstances in which an interpreter or translator is needed in languages or situations for which there is demonstrably no qualified interpreter or translator available. In these circumstances, interpreters or translators may be selected from whatever source available but with as many guarantees as possible built in (Grollmann, Martinsen \& Rasmussen 2001).

Moreover, an enforceable roster lends a backbone to the codes of ethics by imbibing it with a mechanism for monitoring practitioner compliance, including an accessible grievance procedure (Witter-Merithew \& Johnson 2004: 14; Blasco Mayor, del Pozo Triviño, Giambruno, Martin, Ortega Arjonilla, Rodríguez Ortega \& Valero Garcés 2013: 4).

\section{Conclusions}

Although the LIT Search work group findings are not yet available and the national register of remote interpreters in the United States is not yet completed, policy-level mentions of national registers figure rather prominently among recommendations made by a variety of researchers. The US can and should use this work to inform its own beginning forays into building a national register, and the same wisdom could also be of service to healthcare interpreters as well as other types of community/public service interpreters.

As LITs move away from an unregulated industry to a regulated profession, a national register can acknowledge the importance of and lead to compliance with a series of minimum standards to which all practitioners must adhere, including mandatory training (before legitimately offering the service), official recognition of academic qualifications in translation or interpreting, and documented areas of competence. The question remains: can a national register realistically regulate a profession to this extent?

Corsellis reminds us of the vital role that national registers play in the regulation of the profession when she states that:

Part of the role of a regulated profession is to have an appropriate measure of overall national ownership and control of their profession, while collaborating with government and other relevant bodies in the process. There is a need to know, at a basic level, how many qualified practitioners exist, in what language combinations and where, against how many are needed, now and in 
the future. In addition, there is a need to know, disseminate and monitor the types of skills and good practice protocols required, and to keep them up to date. The basic data is needed to inform who and how many are brought into the profession; how they are trained, assessed and accredited; what support systems they need (Corsellis 2011: 151).

As the title of this volume suggests, it is, indeed, a turning point for legal interpreting: a time in which practitioners must make a stand for themselves. If they do not, especially by insisting on the creation and use of a register which makes their objective competences transparent, their working conditions, standards and practices are likely to continue to be decided by others.

\section{Bibliography}

Bell, Roger. (2000) "Pseudo-, Para- or Proto-: What Kind of a Professional is the Translator or Interpreter?" The Linguist: Journal of the Institute of Linguists 39:5, pp. 147-150.

Blasco MaYor, María Jesús; Maribel del Pozo Triviño; Cynthia Giambruno; Anne Martin; Emilio Ortega Arjonilla; Nadia Rodriguez Ortega, \& Carmen Valero Garcés. (2013, July 22). Informe sobre la transposición de la directiva 2010/64/ UE del Parlamento Europeo y del Consejo relativa al derecho a interpretación y traducción en los procesos penales. Electronic version available at: <https:// www.academia.edu/8755014/Informe_sobre_la_transposici\%C3\%B3n_de_ la_Directiva_2010_64_UE_del_Parlamento_Europeo_y_del_Consejo_relativa_al_derecho_a_interpretaci\%C3\%B3n_y_traducci\%C3\%B3n_en_los_procesos_penales>

BlasCo MAYOR, María Jesús. (2013) "Quality of Interpreting in Criminal Proceedings in Spain under European Directive 2010/64/EU." Cuadernos De ALDEEU, 25, pp. 165-190. Electronic version available at: <http://repositori. uji.es/xmlui/bitstream/handle/10234/89189/58951.pdf?sequence=4>

CAPATI, Capati. (2014, June 24) Question about your Work Group on Roster Parameters [E-mail to the author].

Corsellis, Ann. (2000) "Turning Good Intentions into Good Practice: Enabling the Public Services to Fulfil their Responsibilities." In: Roberts, Roda P.; Silvana E. Carr; Diana Abraham \& Aideen Dufour (eds.) 2000. The Critical Link 2: Interpreters in the Community. Selected Papers from the Second International Conference on Interpreting in Legal, Health and Social Service Settings, Vancouver, BC, Canada, 19-23 May 1998. Vancouver, BC: John Benjamins, pp 89-99. DOI: $10.1075 /$ btl.31.11cor

CoRSEllis, Ann. (2004) "Inter disciplinary Conventions \& Toolkits for Legal Services." In: Keijzer-Lambooy, Heleen \& Willem Jan Gasille (eds.) 2004. Aequilibrium. Instruments for Lifting Language Barriers in Intercultural Legal 
Proceedings EU Project JAI/2003/AGIS/048. Utrecht: ITV Hogeschool voor Tolken en Vertalen, pp. 121-134. Electronic version available at: <http://www. eulita.eu/sites/default/files/Aequilibrium_Instruments\%20for\%20Lifting\%20 Language\%20Barriers\%20in\%20Intercultural\%20Legal\%20Proceedings_0. pdf $>$

CORSELLIS, Ann; Jan Cambridge; Nicky Glegg \& Sarah Robson. (2007) "Establishment, Maintenance and Development of a National Register." In: Wadensjö, Cecilia; Birgitta Englund Dimitrova \& Anna-Lena Nilsson (eds.) 2007. The Critical Link 4: Professionalisation of Interpreting in the Community. Selected Papers from the 4th International Conference on Interpreting in Legal, Health and Social Service Settings, Stockholm, Sweden, 20-23 May 2004. Amsterdam; John Benjamins, pp. 139-150.

Corsellis, Ann. (2008) Public Service Interpreting: The First Steps. New York: Palgrave Macmillan.

CORSELLIS, Ann. (2011) "Seven EU Projects - A Journey Towards a Regulated Language Profession.” In: Blasco Mayor, María Jesús \& María Amparo Jiménez Ivars. (eds.) 2011. Interpreting Naturally: A Tribute to Brian Harris. Bern, Berlin, Bruxelles, Frankfurt am Main, New York, Oxford, Wien: Peter Lang, pp. 143-160.

FrANCO AiXelÁ, Javier. (2012) "A Critical Overview of the Translation Studies Journals Published in Spain.” In: García Izquierdo, Isabel \& Esther Monzó Nebot (eds.) 2012. Iberian Sudies on Translation and Interpreting. Bern: Peter Lang, pp. 339-344.

GrollmanN, Doris; Bodil Martinsen \& Kirsten W. Rasmussen. (2001) "Professional Working Arrangements." In: Hertog, Eric (ed.) 2001. Aequitas. Access to Justice across Language and Culture in the EU. 2001. Antwerp: Departement Vertaaler-Tolk - Lessius Hogeschool, pp. 88-92. Electronic version available at: <http://www.eulita.eu/sites/default/files/Aequitas_Acces\%20to\%20Justice $\% 20$ across\%20Language\%20and\%20Culture\%20in\%20the\%20EU.pdf>

HALE, Sandra Beatriz. (2007) Community Interpreting. New York: Palgrave Macmillan.

HelmerichS, Cristina (2004) "Court Interpreting: The U.S. v. EU A Brief Comparison of our Realities.” In: Keijzer-Lambooy, Heleen \& Willem Jan Gasille (eds.) 2004. Aequilibrium. Instruments for Lifting Language Barriers in Intercultural Legal Proceedings EU Project JAI/2003/AGIS/048. Utrecht: ITV Hogeschool voor Tolken en Vertalen, pp. 185-189. Electronic version available at: <http:// www.eulita.eu/sites/default/files/Aequilibrium_Instruments\%20for\%20Lifting\%20Language\%20Barriers\%20in\%20Intercultural\%20Legal\%20Proceedings_0.pdf >

HertoG, Erik \& Jan Van Gucht. (2008) Status Quaestionis: Questionnaire on the Provision of Legal Interpreting and Translation in the EU. Antwerp: Intersentia. 
Hessmann, Jens; Eeva Salmi; Graham H. Turner \& Svenja Wurm. (2011) "Developing and Transmitting a Shared Interpreting Research Ethos. EUMASLI - A Case Study." In: Nicodemus, Brenda \& Laurie Swabey (eds.) 2011. Advances in Interpreting Research. Inquiry in Action. Amsterdam / Philadelphia: John Benjamins, pp. 177-198.

MikKELSON, Holly. (2013) "Universities and Interpreter Certification." Translation and Interpreting 5:1, pp. 66-78. DOI: 10.12807/ti.105201.2013.a03

Monzó, Esther. (2005) "Being ACTIVE in Legal Translation and Interpreting: Researching and Acting on the Spanish Field." Meta: Journal Des Traducteurs / Meta: Translators' Journal 50:4, n.p. DOI: 10.7202/019922ar Electronic version available at: http://id.erudit.org/revue/meta/2005/v50/n4/019922ar.pdf

Monzó, Esther. (2009) "Legal and Translational Occupations in Spain." Translation and Interpreting Studies 4:2, pp. 135-154. DOI: 10.1075/tis.4.2.07mon

Morgan, Caroline. (2011) "The New European Directive on the Rights to Interpretation and Translation in Criminal Proceedings." In: Braun, Sabine \& Judith L. Taylor (eds.) 2011. Videoconference and Remote Interpreting in Criminal Proceedings. Guildford: University of Surrey, pp. 5-10.

Ortega Herráez, Juan Miguel; Cynthia Giambruno \& Erik Hertog. (2013) "Translating for Domestic Courts in Multicultural Regions: Issues and New Developments in Europe and the United States of America." In: Borja Albi, Anabel \& Fernando Prieto Ramos (eds.) 2013. Legal Translation in Context: Professional Issues and Prospects. Bern, Berlin, Bruxelles, Frankfurt am Main, New York, Oxford, Wien: Peter Lang, pp. 89-121.

Perez, Thomas E. (2010, August 16) "Letter written August 16, 2010 to All US state Chief Justices and State Court Administrators." In: Limited English Proficiency (LEP): An Interagency Website. Electronic version available at: http:// www.lep.gov/final_courts_ltr_081610.pdf

PyM, Anthony. (2014) "Translation Studies in Europe - Reasons for it, and Problems to Work On.” Twenty Years EST: Same Place, Different Times. Special Issue of Target 26:2, pp. 185-205.

PyM, Anthony; François Grin; Claudio Sfreddo \& Andy L. J. Chan. (2012, July 24) The Status of the Translation Profession in the European Union. Electronic version available at: <http://ec.europa.eu/dgs/translation/publications/ studies/translation_profession_en.pdf>

Rudvin, Mette. (2014) "Improving the Quality of Legal Interpreter Training and the Recruitment of Interpreters through Intensive Orientation Courses and the Implementation of a Register: The LEGAII Project at the University of Bologna." In: Falbo, Caterina \& Maurizio Viezzi (eds.) 2014. Traduzione e interpretazione per la società e le istituzioni. Trieste: EUT Edizioni Università di Trieste, pp. 73-82. 
SAlaETS, Heidi. (2012) "The Next Step in the CBI Professionalization Process: Training the Public Service Providers." The Interpreters' Newsletter 17, pp. 191-203. Electronic version available at: <http://hdl.handle.net/10077/8628> SCHWEDA Nicholson, Nancy (2004) "The European Commission's Proposal for a Council Framework Decision: The United States' Perspective." In: Keijzer-Lambooy, Heleen \& Willem Jan Gasille (eds.) 2004. Aequilibrium. Instruments for Lifting Language Barriers in Intercultural Legal Proceedings EU Project JAI/2003/AGIS/048. Utrecht: ITV Hogeschool voor Tolken en Vertalen, pp. 35-50. Electronic version available at: <http://www.eulita.eu/sites/default/ files/Aequilibrium_Instruments\%20for\%20Lifting\%20Language\%20Barriers\%20in\%20Intercultural\%20Legal\%20Proceedings_0.pdf >

TSENG, Joseph. (1992) Interpreting as an Emerging Profession in Taiwan - A Sociological Model. New Taipei City: Fu Jen Catholic University. Unpublished master's thesis.

VARIOUS AUTHORS (Conference of State Court Administrators - COSCA). (n.d.) Council of Language Access Coordinators (CLAC) Charter. Electronic version available at: <http://www.ncsc.org/services-and-experts/areas-of-expertise/ language-access/ /media/files/pdf/services $\% 20$ and $\% 20$ experts/areas $\% 20$ of $\% 20$ expertise/language $\% 20$ access/resources $\% 20$ for $\% 20$ program $\% 20$ managers/charter\%20for\%20clac\%203212.ashx>

VARIOUS AUTHORS (European Union). (2010) Directive 2010/64/EU of the European Parliament and of the Council of 20 October 2010 on the Right to Interpretation and Translation in Criminal Proceedings OJ L 280 1-7. Electronic version available at: <http://eur-lex.europa.eu/LexUriServ/LexUriServ. do?uri=OJ:L:2010:280:0001:0007:en:PDF>

VARIOUS Authors. (n.d.) ImPLI Improving Police and Legal Interpreting 20112012 Final Report. Electronic version available at <http://eulita.eu/ impli-improving-police-and-legal-interpreting>

VARIOUS AUTHORS. (n.d.) LIT Search - Pilot Project for an EU Database of Legal Interpreters and Translators. Electronic version available at: <http://www. eulita.eu/lit-search-\%E2\%80\%93-pilot-project-eu-database-legal-interpreters-and-translators>

VARIOUS AUthors. (TRAFUT - Training for the Future). (n.d.) Final Report. Directive 2010/64/EU of the European Parliament and the Council of 20 October 2010 on the Right to Interpretation and Translation in Criminal Proceedings. Electronic version available at: <http://www.eulita.eu/sites/default/files/ TRAFUT\%20-\%20final\%20report.pdf>

WALlaCE, Melissa. (Forthcoming: March 2015) "A Further Call to Action: Prioritizing Quality in Court Interpreting through Research-Driven Recommendations which Link Training and Policy." In: Monzó Nebot, Esther \& L. Cheng (eds.) 2015. Special issue of The Interpreter and Translator Trainer 9:1. 
WinTER, Michael F. (1988) The Culture and Control of Expertise: Toward a Sociological Understanding of Librarianship. Westport, Connecticut: Praeger Publishing.

Witter-Merithew, Anna \& Leilani Johnson. (2004) "Market Disorder within the Field of Sign Language Interpreting: Professionalization Implications." Journal of Interpretation 1-35. Electronic version available at: <http://www. unco.edu/doit/resources/Publication_PDFs/JOI\%20Market\%20Disorder\%20 article.pdf>

\section{BIONOTE / NOTA BIOGRÁFICA}

Melissa Wallace received her Ph.D. in translation and interpreting studies from the Universidad de Alicante, Spain. A certified court interpreter and certified healthcare interpreter, Wallace served two terms as an appointed member of the state Supreme Court Committee to Improve Translation and Interpreting in Wisconsin Courts. She is an active appointed member of the Standards and Training Committee of the National Council on Interpreting in Health Care, a member of the Executive Council of the American Translation and Interpreting Studies Association, and the Chair of the Advisory Council of Voice of Love, a U.S.-based nonprofit that develops training and resources to support interpreting for survivors of torture, war trauma and sexual violence. Her research focuses on indicators of aptitude on court interpreter certification exams, interpreter and translator training, and policy innovations as language access activism. Currently Wallace is an Assistant Professor of TI Studies at the University of Texas at San Antonio where she directs the graduate certificate program in translation studies.

Melissa Wallace obtuvo su doctorado en estudios de traducción e interpretación en la Universidad de Alicante, España. Actualmente es profesora de estudios de traducción e interpretación en la Universidad de Texas en San Antonio, donde dirige el programa de posgrado en estudios de traducción. Es intérprete judicial certificada desde el año 2005 por el estado de Wisconsin, donde ha sido miembro del Comité de la Corte Suprema para mejorar la traducción e interpretación en los tribunales estatales. Es miembro del Comité sobre Normas y Capacitación (Standards and Training Committee) del National Council on Interpreting in Health Care), y también codirige el grupo de trabajo dedicado a la producción de webinarios para capacitadores. Wallace ha sido recientemente invitada a participar en el Consejo Asesor de The Voice of Love, organización estadounidense sin ánimo de lucro que desarrolla programas 
y recursos para apoyar la interpretación para los supervivientes de tortura, trauma de guerra y violencia sexual. Sus investigaciones y publicaciones se centran en los indicadores de aptitud en los exámenes de certificación para los intérpretes jurídicos y en la política lingüística como forma de activismo para eliminar barreras. 